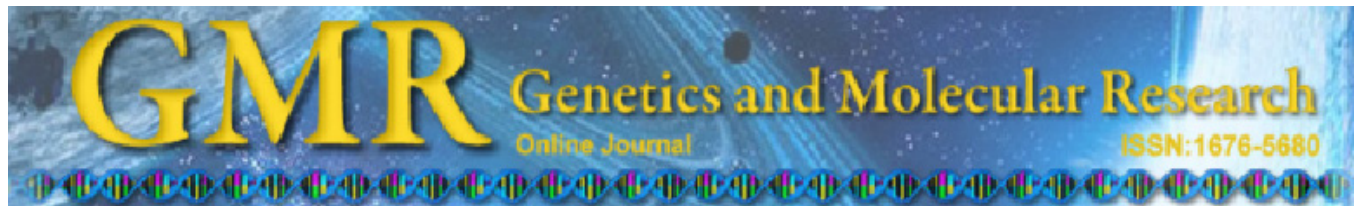

Short Communication

\title{
Isolation and characterization of novel microsatellite markers in commercial selected golden Malaysian arowana fish, Scleropages formosus (Osteoglossidae)
}

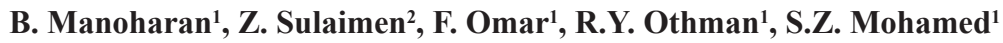
and S. Bhassu ${ }^{1}$

${ }^{1}$ Genomic Research and Breeding Laboratory and Centre for Research in Biotechnology for Agriculture (CEBAR), Institute of Biological Sciences, Faculty of Science, University of Malaya, Kuala Lumpur, Malaysia ${ }^{2}$ Freshwater Fisheries Research Center, Glami Lemi, Jelebu, Negeri Sembilan, Malaysia

Corresponding author: S. Bhassu

E-mail: subhabhassu@yahoo.com

Genet. Mol. Res. 10 (2): 712-716 (2011)

Received July 6, 2010

Accepted December 7, 2010

Published April 26, 2011

DOI 10.4238/vol10-2gmr944

\begin{abstract}
Malaysian arowana (dragonfish; Scleropages formosus) is an ancient osteoglossid fish from southeast Asia. Due to the high demand of the ornamental fish trade and because of habitat loss, the species is close to extinction. We isolated and characterized 10 polymorphic microsatellites of this species, using 5'-anchored PCR. The number of alleles at the 10 microsatellite loci ranged from 2 to 28 , with a mean of 7.8/locus. The observed heterozygosity ranged from 0.03 to 0.93 (mean: 0.39 ), whereas the expected heterozygosity ranged from 0.03 to 0.94 (mean: 0.46 ). Seven microsatellites deviated from Hardy-Weinberg equilibrium, and three conformed to Hardy-
\end{abstract}


Weinberg equilibrium and were in linkage equilibrium. These 10 novel microsatellites should facilitate studies of genetic diversity and population structure of arowana to help plan actions for the conservation of the indigenous Malaysian arowana.

Key words: Scleropages formosus; RAMs; Microsatellites; Genetic variation; Conservation

The golden arowana, Scleropages formosus, is also known as dragonfish, Asian bonytongue or kelisa in Malaysia, and it belongs to the family Osteoglossidae from southeast Asia (Kottelat et al., 1993) and one of the ancestral teleost clades, where it is a primitive fish from the Jurassic era. It is one of the most expensive ornamental fish species in the world. Because of its high value in the ornamental fish industry (Suleiman, 1999), the golden arowana has been excessively captured and traded in Malaysia. The population is facing a sharp decline due to hunting because of commercial interest as an aquarium fish that forces the wild population to be caught in abundance. This is especially true for Malaysian golden arowanas and red arowanas, which have reached a stage of near extinction since 1980 (Dawes et al., 1999). Therefore, they have been listed as an endangered species by the IUCN (International Union for the Conservation of Nature) Red List (2006), and international trade in these fishes is controlled under the Convention on International Trade in Endangered Species of Wild Fauna and Flora (CITES) as an Appendix I protected fish. However, there is no recent development of conservation status by IUCN and inadequate background knowledge on the population structure and diversity of the wild arowana populations. Recent study by Yue et al. (2006) also isolated microsatellites from red arowana. Polymorphic DNA markers are expected to be a highly useful tool for understanding genetic information of the fish. In this study, 10 novel microsatellites were isolated and characterized to facilitate genetic studies of the commercially selected golden arowana fish.

The microsatellite sequences were isolated using a library-enrichment anchored polymerase chain reaction (PCR) primer protocol based on a previously described procedure (Fisher et al., 1996; Kumar et al., 2002; Bhassu et al., 2008). 5'-Anchor PCR was used to amplify the regions located between two microsatellites in genomic DNA of golden arowana. Genomic DNA was extracted from scales using a GF-1 commercial genomic DNA extraction kit (Vivantis Technologies Sdn. Bhd, Malaysia) following the manufacturer protocol. Five degenerate primers were used to amplify the arowana genome: $\mathrm{BP} 5\left(5^{\prime}-(\mathrm{N})_{3} \mathrm{YY}(\mathrm{BM})_{3} \mathrm{~B}(\mathrm{AG})_{6}-3^{\prime}\right)$, BP8 (5'$\left.(\mathrm{K})_{2}(\mathrm{YH})_{3} \mathrm{Y}(\mathrm{GTT})_{5}-3^{\prime}\right), \mathrm{BP} 10\left(5^{\prime}-(\mathrm{K})_{2} \mathrm{DRDRD}(\mathrm{TC})_{10}-3^{\prime}\right), \mathrm{VJ} 1\left(5^{\prime}-(\mathrm{N}) 7 \mathrm{KKVRVRV}(\mathrm{CT}) 10\right.$ $\left.-3^{\prime}\right)$ and VJ2 (5'- NNNKKRVRVCT(CCT) $\left.{ }_{4} \mathrm{C}-3^{\prime}\right)$, where $\mathrm{K}=\mathrm{G} / \mathrm{T}, \mathrm{V}=\mathrm{G} / \mathrm{C} / \mathrm{A}, \mathrm{R}=\mathrm{G} / \mathrm{A}, \mathrm{N}=$ $\mathrm{A} / \mathrm{C} / \mathrm{G} / \mathrm{T}, \mathrm{H}=\mathrm{A} / \mathrm{C} / \mathrm{T}, \mathrm{Y}=\mathrm{T} / \mathrm{C}, \mathrm{B}=\mathrm{C} / \mathrm{G} / \mathrm{T}, \mathrm{D}=\mathrm{A} / \mathrm{G} / \mathrm{T}, \mathrm{M}=\mathrm{A} / \mathrm{C}$, and $\mathrm{S}=\mathrm{C} / \mathrm{G}$. PCR was carried out in a total volume of $10 \mu \mathrm{L}$ containing $\sim 20 \mathrm{ng}$ genomic DNA, 1X PCR buffer, 0.25 $\mathrm{mM}$ each of dATP, dGTP, dCTP, and dTTP, $0.5 \mu \mathrm{M}$ of each primer, 3 to $5 \mathrm{mM} \mathrm{MgCl}, 1.5 \mathrm{U}$ Taq polymerase (Promega) and deionized water. Amplification was performed in a MultiGene Thermal Cycler (Applied Biosystems) with an initial 3-min predenaturation at $96^{\circ} \mathrm{C}$, followed by 35 cycles of denaturation at $94^{\circ} \mathrm{C}$ for $10 \mathrm{~s}$, an appropriate annealing temperature for $10 \mathrm{~s}$ and an extension at $72^{\circ} \mathrm{C}$ for $30 \mathrm{~s}$. A final extension step at $72^{\circ} \mathrm{C}$ for $7 \mathrm{~min}$ was included. PCR products were then cloned into a yTA cloning vector (Yeastern Biotech Co., Ltd.) according to manufacturer instructions with minor modification. Ten recombinant clones from each 
primer were randomly selected for plasmid extraction, followed by DNA sequencing using the BigDye Terminator Cycle Sequencing Ready Reaction Kit (Applied Biosystems) on the ABI PRISM 377 DNA Sequencer. The sequences were screened using the Vector Screen software in NCBI. Results from the BLAST of the clone sequence show that more than $50 \%$ were connected to the fish model Danio rerio, zebrafish. The clone sequences of all degenerate primer were submitted to GenBank. The primers flanking the microsatellite repeat regions were designed using the PRIMER3 program (Rozen and Skaletsky, 1997) with product lengths ranging from 150 to $300 \mathrm{bp}$.

These primers were then used to screen polymorphisms in 30 wild arowana individuals from a natural population. One scale was removed and stored in $70 \%$ ethanol and kept at $-80^{\circ} \mathrm{C}$. The PCR amplifications were performed in a $10-\mu \mathrm{L}$ reaction mixture containing $20 \mathrm{ng}$ genomic DNA, 1X PCR buffer, $0.25 \mathrm{mM}$ of each dNTP, $0.5 \mu \mathrm{M}$ of each forward and reverse primer, 2.5-5.0 $\mathrm{mM} \mathrm{MgCl}, 1.5 \mathrm{U}$ Taq polymerase (Promega) and deionized water. PCR profiles involved: initial denaturation at $95^{\circ} \mathrm{C}$ for $3 \mathrm{~min}$, followed by 35 cycles at $95^{\circ} \mathrm{C}$ for $30 \mathrm{~s}$, annealing temperature (Table 1) for $30 \mathrm{~s}$, and extension at $72^{\circ} \mathrm{C}$ for $30 \mathrm{~s}$ with a final extension at $72^{\circ} \mathrm{C}$ for $7 \mathrm{~min}$ in a MultiGene Thermal Cycler (Applied Biosystems). PCR products were run on a $4 \%(\mathrm{w} / \mathrm{v})$ metaphor agarose gel at $250 \mathrm{~V}$ for $2 \mathrm{~h}$ and $30 \mathrm{~min}$. The 10 polymorphic primer pairs identified were sent for labeling to double confirm the polymorphism. The forward sequence of all the polymorphic primers was labeled with 5' FAM fluorescent dye and determined with GeneScan ${ }^{\text {TM }} 500$ LIZ size standard and ABI PRISM 3100 Genetic Analyzer (Applied Biosystems).

Of the 52 primer sets tested, 10 of them showed reliable polymorphism (Table 1). Among the 10 markers, 4 were dinucleotide microsatellites (SFO_BP10_A39, SFO_BP10_ A43, SFO_VJ1_A7A, and SFO_VJ1_A13), three were mononucleotide repeats (SFO_ BP10_A32, SFO_VJ2_A129A, SFO_VJ2_A135) and single tetra (SFO_VJ2_A133), penta (SFO_BP8_A13) and hexa (SFO BP 8 A 13 A) microsatellite repeats were present. The characteristics of the 10 polymorphic loci are summarized in Table 1 . The average allele number of these markers was 7.8/locus, with a range of 2 to 28 per locus. The observed heterozygosity ranged from 0.03 to 0.93 with an average of 0.39 , whereas the expected heterozygosity averaged 0.46 , ranging from 0.03 to 0.94 . Significant deviations from Hardy-Weinberg expectations were found at loci SFO_BP8_A13, SFO_BP8_A13A, SFO_BP10_A32, SFO_BP10_A39, SFO_VJ2_A129A, SFO_VJ2_A135, and SFO_VJ1_A7A, suggesting heterozygote deficiency $(\mathrm{P}<0.05)$. These deviations may have resulted from a small population size associated with a bottleneck population or small founder population. Three loci (SFO_BP10_A43, SFO_VJ2_A133 and SFO_VJ1_A13) conformed to Hardy-Weinberg equilibrium (Table 1) and showed linkage between all these loci. We used the Micro-Checker software (Van Oosterhout et al., 2004), and there was no large allele drop out and no scoring error present in our data. However, two null alleles (SFO_BP10_A43 and SFO_VJ2_A133) were detected. All these parameters and tests were computed using the Genepop version 3.4 software (Raymond and Rousset, 1995). These newly developed single locus microsatellites for Scleropages formosus will indeed assist the documentation for stock enhancement programs that will be initiated to conserve its existing population found in the natural habitat. This study also aims to document scientific data, which could facilitate the captive breeding program for conservation by acquiring knowledge on the genetic diversity of both the wild and captive population. 


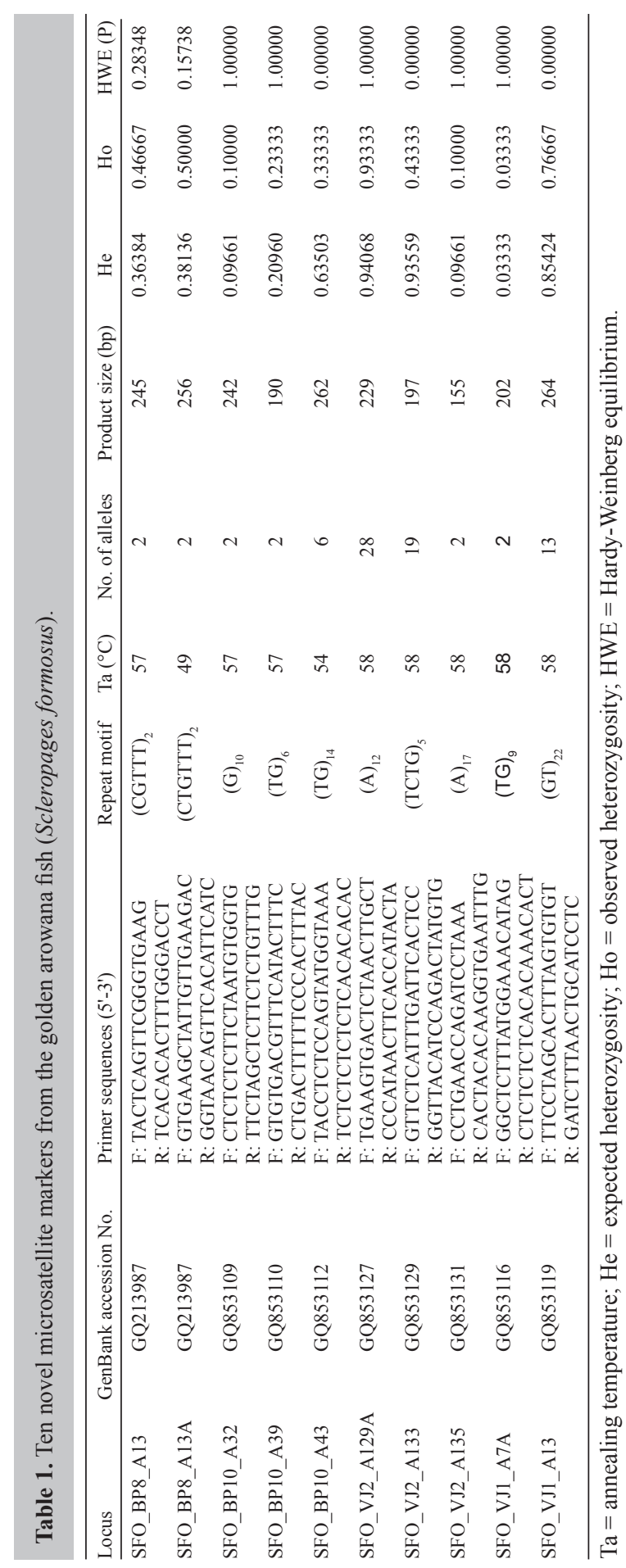




\section{ACKNOWLEDGMENTS}

Research supported by the Ornamental and Aquatic Plants Grant for the 9th Malaysian Fisheries Plan of the Department of Fisheries of Malaysia.

\section{REFERENCES}

Bhassu S, See LM, Hassan R, Siraj SS, et al. (2008). Isolation and characterization of microsatellite loci in the Malaysian giant freshwater prawn, Macrobrachium rosenbergii. Mol. Ecol. Res. 8: 983-985.

Dawes J, Lim LL and Cheong L (1999). The Dragon Fish. Kingdom Books, England.

Fisher PJ, Gardner RC and Richardson TE (1996). Single locus microsatellites isolated using 5'-anchored PCR. Nucleic Acids Res. 24: 4369-4371.

Kottelat M, Whitten AJ, Kartikasari SN and Wirjoatmodjo S (1993). Freshwater Fishes of Western Indonesia and Sulawesi. Periplus Editions, Jakarta.

Kumar SV, Tan SG, Quah SC and Yusoff K (2002). Isolation of microsatellite markers in mungbean, Vigna radiata. Mol. Ecol. Notes 2: 96-98.

Raymond M and Rousset F (1995). Genepop (version 1.2): a population genetics software for exact test and ecumenicism. J. Hered. 86: 248-249.

Rozen S and Skaletsky HJ (1997). Primer 3. Available at [http://frodo.wi.mit.edu/]. Accessed 2008.

Suleiman MZ (1999). Pembiakan Ikan Arowana, Scleropages formosus (Muller and Schlegel). Risalah Perikanan Bil. Jabatan Perikanan Malaysia, Shah Alam, 67: 17.

Van Oosterhout CV, Hutchinson WF, Wills DPM and Shipley P (2004). Micro-checker: software for identifying and correcting genotyping errors in microsatellite data. Mol. Ecol. Notes 4: 535-538.

Yue GH, Zhu ZY, Lin G, Lo LC, et al. (2006). Novel polymorphic microsatellites for studying genetic diversity of red Asian Arowanas. Conserv. Genet. 7: 627-629. 